\title{
Maintenance therapy with infliximab for paediatric Crohn's disease: impact on clinical remission and mucosal healing in Polish paediatric patients with severe Crohn's disease
}

\author{
Terapia podtrzymująca infliksymabem $\mathrm{w}$ leczeniu dzieci $\mathrm{z}$ chorobą \\ Leśniowskiego-Crohna - wpływ na indukcję remisji i gojenie śluzówkowe \\ u dzieci z ciężką postacią choroby Leśniowskiego-Crohna w Polsce
}

\author{
Jarosław Kierkus ${ }^{1}$, Maciej Dądalski¹, Sylwia Szymanska², Edyta Szymanska², Agnieszka Wegner', \\ Monika Górczewska', Grzegorz Oracz', Marek Woynarowski', Józef Ryżko ${ }^{1}$ \\ 1Department of Gastroenterology, Hepatology and Immunology, The Children Memorial Health Institute, Warsaw, Poland \\ 2Medical University of Warsaw, SKN (Studencke Koło Naukowe) at the Department of Gastroenterology, Hepatology and \\ Immunology, The Children Memorial Health Institute, Warsaw, Poland
}

Przegląd Gastroenterologiczny 2012, 7 (1): 26-30

DOI: $10.5114 / p g .2012 .27219$

Key words: Crohn's disease, mucosal healing, biological maintenance therapy.

Słowa kluczowe: choroba Leśniowskiego-Crohna, gojenie śluzówkowe, terapia biologiczna.

Address for correspondence: Jarosław Kierkuś MD, Department of Gastroenterology, Hepatology and Immunology, The Children's Memorial Health Institute, 20 Al. Dzieci Polskich, 04-730 Warsaw, Poland, phone/fax: +48 2281573 92, e-mail: j.kierkus@czd.pl

\begin{abstract}
Introduction: Infliximab (IFX) is currently registered for use in Crohn's disease (CD) in children over 7 years of age. So far, there are not enough satisfactory data on maintenance therapy with IFX in children with CD from Eastern and Medium Europe.

Aim: Therefore, we carried out this trial in order to assess the benefit of maintenance therapy with infliximab in paediatric patients with active Crohn's disease who responded to induction therapy with 3 doses of infliximab.

Material and methods: The study group consisted of $32 \mathrm{CD}$ children aged 14.8; 12.9; 16.3 (median; Q1; Q3) with active Crohn's disease (Crohn's Disease Activity Index (PCDAI) > 30) who have finished induction therapy with infliximab (5 mg/ $\mathrm{kg}$ ) in three repeated infusions. After assessment of remission at week 10 , patients were assigned repeat $5 \mathrm{mg} / \mathrm{kg}$ infliximab every 8 weeks thereafter until week 46; weeks 14,22 , $30,38,46$. The clinical activity of the disease by means of the PCDAI and endoscopic activity by means of the SES-CD together with laboratory tests were assessed at week 10 and 50. Adverse events monitoring had been conducted. Descriptive data analysis was performed with Statistica (StatSoft Polska) ver. 5.11 software package. A non-parametric statistical hypothesis test, Mann-Whitney $U$ test, was used to assess whether two independent samples of observations had equally large values. Value of $p<0.05$ was regarded as significant.
\end{abstract}

\section{Streszczenie}

Wstęp: Infliksymab jest lekiem zarejestrowanym w terapii choroby Leśniowskiego-Crohna (Crohn's disease - CD) u dzieci powyżej 7. roku życia. Dotychczas opublikowano niewiele prac dotyczących skuteczności terapii biologicznej w podtrzymaniu remisji u pacjentów pediatrycznych w krajach Europy Zachodniej i Środkowej.

Cel: Ocena skuteczności terapii infliksymabem w podtrzymaniu remisji u polskich dzieci z CD.

Materiat i metody: Grupę badaną stanowiło 32 dzieci z CD w wieku 14,2, 12,1, 16,5 roku (mediana; Q1; Q3), które ukończyły terapię indukcyjną infliksymabem $(5 \mathrm{mg} / \mathrm{kg}$ m.c. w trzech infuzjach - odpowiednio 0, 2., 6. tydzień), uzyskały odpowiedź kliniczną w skali PCDAI i zostały zakwalifikowane do terapii podtrzymującej - $5 \mathrm{mg} / \mathrm{kg}$ m.c. w infuzjach co 8 tygodni (odpowiednio 14., 22., 30., 38., 46. tydzień). U każdego pacjenta dokonano oceny klinicznej choroby (PCDAl, masa ciała, wzrost, wskaźnik masy ciała (body mass index - BMI)) oraz laboratoryjnej (białko C-reaktywne-CRP, płytki krwi), odpowiednio w 10. i 50. tygodniu terapii infliksymabem, licząc od momentu podania pierwszej dawki indukcyjnej tego leku. U każdego pacjenta w 10. i 50. tygodniu wykonano badanie endoskopowe dolnego odcinka przewodu pokarmowego w celu oceny zmian śluzówkowych (uproszczona skala SES-CD). Statystykę opisową danych wykonano za pomocą pakietu statystycznego Statistica (StatSoft Polska) ver. 5.11. Do oceny różnic pomiędzy wartościa- 
Results: Fourteen patients (44\%) had reached clinical remission (defined as PCDAI score $\leq 10)$ at week 10 , and $23(72 \%)$ at week 50, after the whole maintenance therapy. Comparing data from baseline and week 50, a significant decrease $(p<0.05)$ was found in PCDAl score $(12.5 ; 6.2 ; 15.0$ (median; Q1; Q3) vs. $5.0 ; 0.0 ; 12.5)$ and a significant increase in body mass index (17.5; 15.4; $19.4 \mathrm{~kg} / \mathrm{m}^{2}$ vs. $\left.18.0 ; 16.7 ; 20.0 \mathrm{~kg} / \mathrm{m}^{2}\right)$. No significant changes in inflammatory parameters (C-reactive protein (CRP) and platelets (PLT)) were reported. We found no significant decrease in SES-CD score (3.5; 0.0; 10.0 vs 4.0; $0.0 ; 7.5)$ (median; Q1; Q3), $p>0.05$, between initial and control colonoscopy. No adverse event leading to therapy termination was observed.

Conclusions: Maintenance therapy with infliximab is efficient in maintaining remission of disease and mucosal healing. Maintenance therapy with infliximab improves nutritional status and growth in children with Crohn's disease.

\section{Introduction}

Crohn's disease (CD) is a chronic inflammatory disorder of the gastrointestinal tract that is defined by relapsing and remitting episodes, with progression over time to complications of stricture, fistulas, or abscesses [1]. Inflammatory bowel disease (IBD) develops during childhood or adolescence in up to $25 \%$ of patients [2]. In children, both the disease and its treatment, which can include corticosteroids and immunomodulatory agents, can often result in significant long-term effects that include growth failure, osteopenia, and pathological fractures [3, 4]. The "ideal" treatment of CD should therefore probably not only consist of the suppression of symptoms, but if at all possible also modification of the natural course of the disease. A major step forward in the care for CD was the introduction of biological therapies directed against cytokines or soluble factors [5]. Several randomized placebo-controlled studies clearly showed that the biological drug infliximab (IFX), directed against soluble and membrane-bound tumour necrosis factor- $\alpha$, is highly efficacious in improving the clinical course in adult and paediatric CD patients [6-8]. Data from the paediatric REACH study indicate that after 1 year of scheduled IFX therapy with concurrent immunomodulator medication, 29 of 52 patients with $C D$ remained in remission without IFX dose adjustment [6]. The Accent I-trial has demonstrated that patients with CD who had responded to an initial dose of infliximab were more likely to be in remission at weeks 30 and 54, to discontinue [9]. Moreover, recent studies revealed that patients with "refractory" CD treated with IFX not only had rapid and important clinical improvement, but that this "response" was accompanied by thorough mucosal healing as well [10-12]. mi danych uzyskanych z dwóch niezależnych populacji (dwóch badanych grup) wykorzystano test $U$ Manna-Whitneya. Wartości $p<0,05$ uznano za znamienne.

Wyniki: U 14 z 32 chorych (43,7\%) zaobserwowano remisję kliniczną (PCDAI $\leq 10$ pkt) w 10. tygodniu terapii, a u $23(71,8 \%)$ po zakończeniu leczenia (50. tydzień). Porównując końcowe wyniki $z$ danymi wyjściowymi, odnotowano znaczne $(p<0,05)$ zmniejszenie punktacji w skali PCDAl: odpowiednio 12,5, 6,2, 15,0 (mediana; Q1; Q3) vs 5,0, 0,0, 12,5 oraz istotne statystycznie zwiększenie stężenia hemoglobiny, masy ciała i wzrostu. Nie odnotowano istotnych zmian dotyczących BMI, CRP i liczby płytek krwi. Nie obserwowano dalszej poprawy w gojeniu śluzówkowym w 50. tygodniu terapii. U żadnego pacjenta nie zaobserwowano poważnych działań niepożądanych lub zaostrzeń choroby podstawowej, które mogłyby spowodować przerwanie badania.

Wnioski: Terapia podtrzymująca infliksymabem jest skuteczna w utrzymaniu remisji choroby i wygojeniu zmian śluzówkowych, poprawia stan odżywienia i zwiększa wzrost dzieci z CD.

\section{Aim}

The aim of this study was to evaluate the efficacy of maintenance therapy with IFX in children with severely active $C D$ and its impact on mucosal healing using SES-CD - the Simple Endoscopic Score for Crohn's Disease. It is a simple, reproducible, and easy-to-use endoscopic scoring system for Crohn's disease based on 4 endoscopic variables (ulcer size, ulcerated and affected surfaces, stenosis) in 5 ileocolonic segments and the endoscopic parameters are scored from 0 to $3[13,14]$.

\section{Material and methods}

We analysed 33 children at age 14.2, 12.1, 16.5 years (median; Q1; Q3) with severely active CD who received infliximab. The diagnosis of CD was confirmed by endoscopy and biopsy. Patients were qualified for biological therapy according to the high disease activity index (Paediatric Crohn's disease activity index = PCDAl > 30) and lack of response to conventional therapy (steroids and immunomodulators). They received infliximab $5 \mathrm{mg} / \mathrm{kg}$ at weeks 0-2-6 - induction therapy. All of them were receiving concomitant treatment with an immunomodulator (azathioprine or methotrexate) due to the severe course of the disease. Four weeks later (at week 10), patients were evaluated for a clinical response to treatment as defined as a decrease from baseline in the PCDAI score of at least 15 points, with a total score of 30 or less. Patients who met these criteria, assessed by the principal investigators, were assigned repeat $5 \mathrm{mg} / \mathrm{kg}$ infliximab every 8 weeks thereafter until week 46.

The primary objective to evaluate was clinical and endoscopic activity of disease in patients who received maintenance therapy with infliximab. Patients were 
Table I. Characteristics of patients at week 10 and week 50 - median (range)

Tabela I. Wyniki uzyskane w 10. i 50. tygodniu leczenia - mediana (dolny, górny przedziat)

\begin{tabular}{lll} 
Parameter & \multicolumn{1}{c}{ Week 10 } & \multicolumn{1}{c}{ Week 50 } \\
\hline PCDAl & $12.5(6.2,15.0)$ & $5.0(0.0,12.5)$ \\
\hline Body mass $[\mathrm{kg}]$ & $43.0(36.2,50.7)$ & $48.6(42.0,53.5)$ \\
\hline Height $[\mathrm{cm}]$ & $154.3(142.0,164.5)$ & $158.5(152.0,168.5)$ \\
\hline $\begin{array}{l}\text { Body mass index } \\
{\left[\mathrm{kg} / \mathrm{m}^{2}\right]}\end{array}$ & $17.9(16.4,19.5)$ & $18.9(16.9,20.0)$ \\
\hline SES-CD & $3.5(0.0,10.0)$ & $4.0(0.0,7.5)$ \\
\hline Platelets (PLT) & $308.0(277.5,460.5)$ & $342.5(281.0,501.5)$ \\
\hline Haemoglobin $[\mathrm{mg} \%]$ & $10.9(9.8,11.2)$ & $11.9(10.1,12.8)$ \\
\hline C-reactive protein & $0.3(0.15,2.9)$ & $0.8(0.2,3.0)$
\end{tabular}

assessed at week 10 (baseline) and subsequently every 8 weeks during visits at weeks $14,22,30,38,46$, and 50 (end point). At each visit, the components of the PCDAI score such as linear growth, subjectively reported symptoms and laboratory parameters of intestinal inflammation were measured [15]. Clinical remission was defined as PCDAI < 10; clinical response as decrease in PCDAI score over 15 and $P C D A I<30$. Colonoscopies were performed before treatment and at week 10. Selected endoscopic parameters (ulcer size, ulcerated and affected surfaces, stenosis) were scored from 0 to 3 using SES-CD performed for each colonoscopy. Mucosal healing was defined as entire lack of ulcers or significant decrease in SES-CD (as a sign of inflammatory lesions decrease) accompanied by ulcerated surfaces, while stationary endoscopic features stood for lack of progression or regression. Table I presents patients' characteristics at week 10 and week 50 (after whole maintenance therapy).

Adverse events monitoring was conducting during the whole study period. Data for all of the 33 study participants were reported according to the actual treatment received and are included in the safety analyses. At each visit, adverse events were documented, and blood samples for clinical laboratory evaluations were obtained.

\section{Statistical analysis}

Descriptive data analysis was performed using Statistica (StatSoft Polska) ver. 5.11 software package. To assess whether two independent samples of observations had equally large values, a non-parametric statistical hypothesis test, Mann-Whitney $U$ test, was used. Value of $p<0.05$ was regarded as significant. To compare data obtained at week 10 and week 50 for two independent paired samples, Wilcoxon signed-rank test was used. Value of $p<0.05$ was regarded as significant. To compare qualitative variables between the groups, a $\chi^{2}$ test together with Fisher's exact test for small samples was used. Value of $p<0.05$ was regarded as significant.

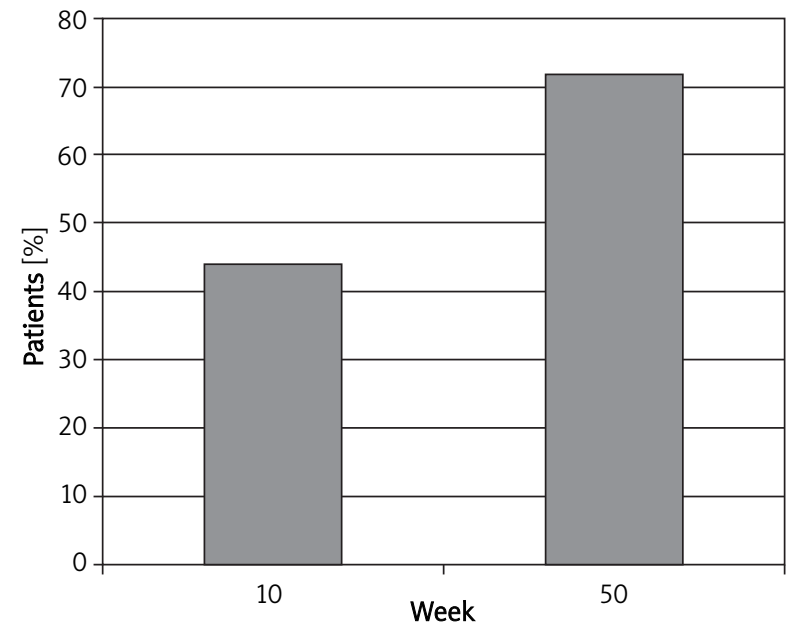

Fig. 1. Percentage of patients in remission at week 10 and week 50 of therapy with infliximab Ryc. 1. Odsetek pacjentów, którzy uzyskali remisję w 10. i 50. tygodniu terapii infliksymabem

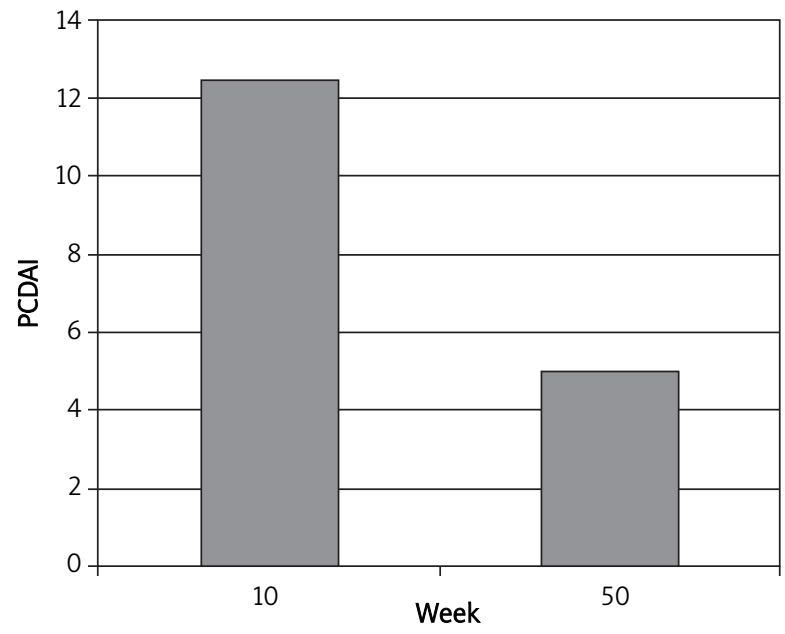

Fig. 2. PCDAl score of patients in remission at week 10 and week 50 of therapy with infliximab Ryc. 2. Średnie wartości punktacji PCDAl u pacjentów w 10. i 50. tygodniu leczenia infliksymabem 


\section{Results}

Figures 1-2 present the results of maintenance therapy with IFX in the study group. Fourteen patients (44\%) had reached clinical remission (defined as PCDAI score $\leq 10)$ at week 10 , and $23(72 \%)$ at week 50 , after the whole maintenance therapy. Symptoms stabilization, increase in general well-being and in biochemical parameters, reflected by a significant decrease $(p<0.05)$ in PCDAl score, was found in all patients who underwent maintenance therapy with the following results: 12.5, 6.2, 15.0 (median, Q1; Q3) vs. 5.0, 0.0, 12.5. No significant changes in inflammatory parameters (C-reactive protein - CRP and PLT) were reported. However, a significant increase in body mass index (BMI) $\left(17.5,15.4,19.4 \mathrm{~kg} / \mathrm{m}^{2}\right.$ vs. $\left.18.0,16.7,20.0 \mathrm{~kg} / \mathrm{m}^{2}\right)$ was found when comparing data from baseline and week 50, which expressed an improvement in nutritional status of our patients. We found no significant decrease in SES-CD score (3.5, 0.0, 10.0 vs. 4.0, 0.0, 7.5) (median; Q1; Q3), $p>0.05$, between initial and control colonoscopy. There were no deaths, malignancies, central nervous system demyelinating disorders, optic neuritis, or seizures during the study. No AE leading to therapy termination was observed.

\section{Discussion}

Available data $[6,16-18]$ show that biological therapies which target tumour necrosis factor- $\alpha$ (TNF- $\alpha$ ) are effective in the treatment of moderately to severely active $C D$ in children. The IFX, already registered in paediatrics, seems not only to induce, but also to maintain remission in $C D$ patients $[6,7]$. Hyams et al. were the first to analyse paediatric patients and they proved that maintenance therapy with IFX given every 8 weeks leads to long-lasting remission in $58 \%$ of patients [6]. ACCENT I, a randomized control trial, is the biggest meta-analysis of efficacy of maintenance therapy with IFX. The authors analysed 573 CD patients with a score of at least 220 on the Crohn's disease activity index (CDAI) who received a $5 \mathrm{mg} / \mathrm{kg}$ intravenous infusion of infliximab at week 0 , and after assessment of response at week 2 were randomly assigned repeat infusions of different doses of IFX $(5 \mathrm{mg} / \mathrm{kg}$ and $10 \mathrm{mg} / \mathrm{kg}$, respectively) and were compared to the patients receiving placebo. Their results showed that patients who responded to an initial dose of infliximab were more likely to be in remission at follow-up time and to discontinue corticosteroids than patients who received placebo. In addition, they proved that the response is maintained for a longer period if therapy with IFX is maintained every 8 weeks at high (10 mg/kg) doses (38\% vs. $28 \%$, respectively) [7].

Our results confirm the presented outcomes. In our study, 23 patients (72\%) who received repeat $5 \mathrm{mg} / \mathrm{kg}$ infliximab every 8 weeks until week 46 were in clinical remission, defined as PCDAI < 10 (72\%), at week 50 (after whole maintenance therapy), defined as PCDAl $<10$. We also observed a significant improvement in nutritional status of our patients, which was expressed through increase in both BMI and body mass. Unfortunately, so far, we do not possess any significant proper data regarding the efficacy of biological therapy in children lasting longer than 1 year. However, this kind of treatment is undoubtedly highly efficient, especially when administered in repeated scheduled IFX infusions $[19,20]$. Therefore, a top-down approach using biological therapy early or more aggressive treatment through the use of IFX along with azathioprine to induce remission in CD is currently under study [21-23]. Although the preliminary results are optimistic, they still require additional evidence-based data on bigger groups of patients, especially children. A high efficacy of maintenance therapy with IFX not only provides a longer sustained remission, but also changes the natural history of the disease [24, 25]. The results of our study confirm previous reports that 1-year maintenance therapy with $5 \mathrm{mg} / \mathrm{kg}$ IFX every 8 weeks provides sustained clinical benefits over the long term and improvement in nutritional status in children with Crohn's disease.

\section{References}

1. Cosnes J, Cattan S, Blain A, et al. Long-term evolution of disease behavior of Crohn's disease. Inflamm Bowel Dis 2002; 8: 244-50.

2. Benchimol El, Fortinsky KJ, Gozdyra P, et al. Epidemiology of pediatric inflammatory bowel disease: a systematic review of international trends. Inflamm Bowel Dis 2011; 17: 423-39.

3. Motil KJ, Grand RJ, Davis-Kraft L, et al. Growth failure in children with inflammatory bowel disease: a prospective study. Gastroenterology 1993; 105: 681-91.

4. Semeao EJ, Jawad AF, Zemel BS, et al. Bone mineral density in children and young adults with Crohn's disease. Inflamm Bowel Dis 1999; 5: 161-6.

5. Sandborn WJ, Targan SR. Biologic therapy of inflammatory bowel disease. Gastroenterology 2002; 122: 1592-608.

6. Hyams J, Crandall W, Kugathasan S, et al. Induction and maintenance infliximab therapy for the treatment of moderate-tosevere Crohn's disease in children (REACH study). Gastroenterology 2007; 132: 863-73.

7. Hanauer SB, Feagan BG, Lichtenstein GR, et al. ACCENT I Study Group. Maintenance infliximab for Crohn's disease: the ACCENT I randomized trial. Lancet 2002; 359: 1541-9.

8. Rutgeerts P, Feagan BG, Lichtenstein GR, et al. Comparison of scheduled and episodic treatment strategies of infliximab in Crohn's disease. Gastroenterology 2004; 126: 402-13.

9. Hanauer SB, Feagan BG, Lichtenstein GR, et al. Maintenance infliximab for Crohn's disease: the ACCENT I randomised trial. Lancet 2002; 1541-9.

10. D'Haens G, Van Deventer S, Van Hogezand R, et al. Endoscopic and histological healing with infliximab antibodies in 
Crohn's disease: a European multicenter trial. Gastroenterology 1999; 116: 1029-34.

11. Rutgeerts P, Van Assche G, Van Deventer S, et al. Infliximab maintenance treatment strategy results in mucosal healing in patients with Crohns disease. Gastroenterology 2002; 122: A618.

12. D'Haens G, Noman M, Baert F, et al. Endoscopic healing after Infliximab treatment for Crohn's disease provides a longer time to relapse. Gastroenterology 2002; 122: A100.

13. Daperno M, D’Haens G, Van Assche G, et al. Development and validation of a new, simplified endoscopic activity score for Crohn's disease: the SES-CD. Gastrointest Endosc 2004; 505-12.

14. Hyams JS, Ferry GD, Mandel FS, et al. Development and validation of a pediatric Crohn's disease activity index. J Pediatr Gastroenterol Nutr 1991; 12: 439-47.

15. IBD Working Group of the European Society for Paediatric Gastroenterology, Hepatology and Nutrition. Inflammatory bowel disease in children and adolescents: recommendations for diagnosis: the Porto criteria. J Pediatr Gastroenterol Nutr 2005; 41: 1-7.

16. Cohen R, Tsang J, Hanauer S. Infliximab in Crohn's disease: first anniversary clinical experience. Am J Gastroenterol 2000; 95: 3469-77.

17. Rutgeerts $\mathrm{P}$, Diamond $\mathrm{RH}$, Bala $\mathrm{M}$, et al. Scheduledmaintenance treatment with infliximab is superior to episodic treatment for the healing of mucosal ulceration associated with Crohn's disease. Gastrointest Endosc 2006; 63: 433-42.

18. Ricart E, Panaccione R, Loftus E, et al. Infliximab for Crohn's disease in clinical practice at the Mayo Clinic: the first 100 patients. Am J Gastroenterol 2001; 96: 722-9.

19. Wynands J, Belbouab R, Candon S, et al. 12-month follow-up after successful infliximab therapy in pediatric crohn disease. J Pediatr Gastroenterol Nutr 2008; 46: 293-8.

20. Rutgeerts P, Feagan BG, Lichtenstein GR, et al. Comparison of scheduled and episodic treatment strategies of infliximab in Crohn's disease. Gastroenterology 2004; 126: 402-13.

21. Rutgeerts $P$, Vermeire S, Van Asche G. Mucosal healing in inflammatory bowel disease: impossible ideal or therapeutic target? Gut 2007; 56; 453-5.

22. Ghosh S, lacucci M. Mucosal healing in inflammatory bowel disease. Eur Gastroenterol Hepatol Rev 2010; 6: 11-8.

23. de Carpi M, Masiques J, García Romero L, et al. Top-down therapy with infliximab and azathioprine in newly diagnosed paediatric Crohn's disease. J Pediatr Gastroenterol Nutr 2006; 43: S42.

24. Vermeire S, et al. Altering the natural history of Crohn's disease - evidence for and against current therapies. Aliment Pharmacol Ther 2007; 25: 3-12.

25. Hyams JS, Markowitz JF. Can we alter the natural history of Crohn disease in children? J Pediatr Gastroenterol Nutr 2005; 40: 262-72. 